\title{
Permian stromatolites associated with bivalve coquina beds- Angatuba, SP, Brazil (Teresina Formation, Paraná Basin)
}

\author{
William Sallun Filho, Renato Pirani Ghilardi, \\ Loreine Hermida Silva e Silva and Jorge Hachiro
}

\begin{abstract}
Silicified stromatolites have been described in the Permian Teresina Formation, Passa Dois Group, of the Paraná Basin. These stromatolites occur as blocks in the Fazenda Monte Alegre area at the headwaters of the creek known as Córrego Catanduva in the municipality of Angatuba. These blocks originate from the Serra de Angatuba region and were recognized in a road that was cut in the midst of sandstones and siltites. The stromatolites are isolated bioherms that are domed to subspherical with a flat base in profile and a rounded to lenticular shape in plan view. The stromatolites exhibit a reddish coloration and are composed of microcrystalline quartz. Lamination is continuous, non-columnar, and anastomosed, showing parallel to divergent growth; however, divergent columns also occur, especially at the tops of the bioherms. The lamination is fine and well preserved, with alternating light and dark laminas. Microfossils of filamentous cyanobacteria are preserved and were related to the genera Microcoleus and Rivularia. Silicified bivalves occur in association with the stromatolites and are preserved in the form of coquina beds and rare isolated specimens within the bioherms. The described specimens belong to the Pinzonella illusa biozone, with representatives of the species Pinzonella illusa, Angatubia cowperesioides, and Houldausiella elongata. The formation environment of these stromatolites is associated with tidal plains of shallow, brackish, relatively calm, warm waters of good luminosity with the presence of weak currents. There was likely a low level of predation, and the environment may have been hypersaline. The coquina beds associated with the stromatolites indicate a probable proximal tempestite, i.e., they were formed near the coastline. The stromatolites were originally composed of carbonates, although these were replaced by silica during early diagenesis.
\end{abstract}

William Sallun Filho. Instituto Geológico, Secretaria do Meio Ambiente do Estado de São Paulo, Av. Miguel Stéfano, 3900, 04301-903, São Paulo, SP, Brasil. wsallun@gmail.com

Renato Pirani Ghilardi. Departamento de Ciências Biológicas, Faculdade de Ciências, UNESP-Bauru, Av. Eng. Luiz Edmundo Carrijo Coube, s/n, 17033-360, Bauru, SP, Brasil. ghilardi@fc.unesp.br

Loreine Hermida Silva e Silva. Universidade Federal do Estado do Rio de Janeiro, Av. Pasteur 458, Bloco III, 22290-240, Rio de Janeiro, RJ, Brasil. Ioreineh@unirio.br

Jorge Hachiro. Instituto de Geociências, Universidade de São Paulo, Rua do Lago, 562, 05508-080, São

Paulo, SP, Brasil. jhachiro@usp.br

PE Article Number: 15.1.7A

Copyright: Palaeontological Association March 2012

Submission: 25 May 2010. Acceptance: 24 November 2011

Sallun Filho, William, Ghilardi, Renato Pirani, Silva e Silva, Loreine Hermida, and Hachiro, Jorge. 2012. Permian stromatolites associated with bivalve coquina beds_Angatuba, SP, Brazil (Teresina Formation, Paraná Basin). Palaeontologia Electronica Vol. 15, Issue 1; 7A, 16p;

palaeo-electronica.org/content/2012-issue-1-articles/182-permian-stromatolites 
Keywords: Stromatolite; Coquina bed; Permian; Paraná Basin; Teresina Formation; Brazil

\section{INTRODUCTION}

Stromatolites are known in various Brazilian geological units, principally in carbonate rocks of the Proterozoic age, although they have not been extensively studied to date. The work of de Almeida (1944) marked the beginning of studies on stromatolites in Brazil (and Latin America). In the 1950s and 1960s, de Almeida went on to register other important occurrences of these fossils in the Estrada Nova Formation (Paraná Basin) in the Alto Araguaia region (state of Mato Grosso), these being the first found in Phanerozoic rocks in Brazil (de Almeida, 1954).

Stromatolites have been described in Permian deposits of the Paraná Basin, more specifically, in the Irati (Fairchild et al., 1985; Branco et al., 1999), Corumbataí (Suguio and Sousa, 1985) and Estrada Nova (Rohn and Fairchild, 1986; Maranhão, 1995; Maranhão and Petri, 1996) formations.

In the Teresina Formation, chert occurrences were found by Mendes (1962) in the Angatuba region, without recognizing their stromatolitic origin. In the same region, Fúlfaro (1970) described a silicified structure of unknown origin, which Sousa (1985) recognized as a large biohermal structure of stromatolitic origin. At the same location, Maranhão (1995) described the occurrence of nodular stromatolites.

There are few studies about stromatolites in Brazil, especially in Phanerozoic rocks. In the Paraná Basin, one of the largest basins of South America, several stromatolite occurrences have been recorded, but few detailed studies have been performed. In this basin, as well as in various parts of the world, stromatolites were abundant in the Early Triassic and Upper Permian (Schubert and Bottjer, 1992; Castle and Rodgers, 2009).

This study describes, for the first time, silicified stromatolites with well-preserved microfossils of cyanobacteria that are associated with coquina beds found in the Teresina Formation at a new location in the Angatuba region (state of São Paulo).

\section{GEOLOGICAL CONTEXT}

Milani (1997) considers the Passa Dois Group to be part of the Carboniferous-Eopaleozoic Supersequence that he named Gondwana I. According to Milani et al. (2007), the Gondwana I Superse- quence represents a complete transgressiveregressive cycle, with peak transgression in the Artinskian and regression at the entrance of continental depositional systems in the Triassic. These authors indicate that the intracratonic nature of the basin was established in the Gondwana I Supersequence, with the progressive closure of marine connections to the west and confinement in the arid continental environment of the Mesozoic.

A progressive continentalization occurred in the Paraná Basin region during the Permian, which is represented by the Passa Dois Group (FerreiraOliveira and Rohn, 2010).

According to the CPRM (2006), the Teresina Formation is composed of argillites, siltites, and dark gray to greenish, very fine, and fine sandstones of tabular or lenticular geometry. The IPT (1981) describes the same formation as alternating layers of shales, argillites, siltites, and localized fine sandstones and, in the upper portion of the unit, layers of limestone and chert.

The fossiliferous assemblage present in the Teresina Formation comprises sponges (spicules), ostracods, ichthyofossils, coprolites, probable biogenic fragments, charophyte oogonia, bivalves, and stromatolites (Maranhão and Petri, 1996) and conifer (Fanton et al., 2006). Various authors have discussed whether the Teresina Formation is marine or non-marine in nature due to the absence of typically marine fossils (IPT, 1981; CPRM, 2006). The high rate of recovery of ostracods in the Teresina Formation indicates a shallow-water environment, with greater availability of carbonate and stable conditions in terms of temperature and oxygenation (Maranhão and Petri, 1996). The bivalves of the Teresina Formation do not show morphofunctional characteristics that allow them to be classified as exclusively fresh water (Ghilardi and Simões, 2002). The epidermal characteristics of Krauselcladus, a conifer found in the upper Teresina Formation in South Brazil, indicates arid climatic conditions on the continent (Fanton et al., 2006).

Despite a lack of consensus regarding the age of the Teresina Formation, it is positioned between the mid- and lower Permian (Figure 1). A recent $\mathrm{U}-\mathrm{Pb}$ zircon dating of the Serrinha Member (upper portion of the Passa Dois Group) indicated an age of $266.3 \pm 4.6 \mathrm{Ma}$ (Rocha-Campos et al., 


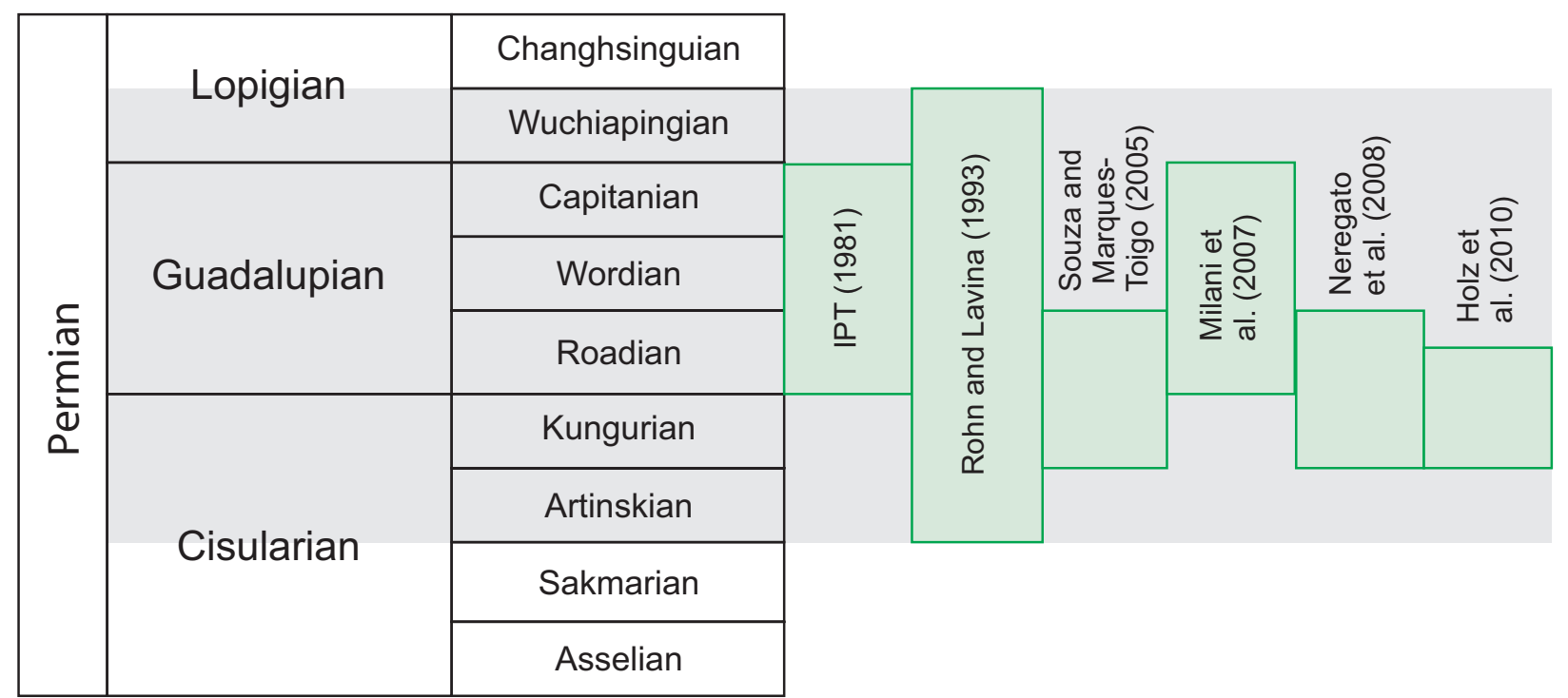

FIGURE 1.Summary table of the geochronological positioning of the Teresina Formation (subdivision proposed by Walker and Geissman, 2009).

2009), placing the Teresina Formation in more ancient periods.

In the Angatuba region, there are outcrops of rocks of the Teresina Formation (IPT, 1981; CPRM, 2006), which, in conjunction with the Serra Alta and Rio do Rasto Formations, comprise the basal portion of the Paraná Basin Passa Dois Group (Figure 2). In addition to the Teresina Formation, there are outcrops of Permian rocks of the Guatá Group (Tatui Formation), together with Mesozoic rocks of the São Bento Group (Pirambóia and Serra Geral Formations) (CPRM, 2006).

Mendes (1962) positioned the Angatuba fossiliferous assemblage in the Pinzonella illusa-Plesiocuprinella carinata biozone and interpreted the paleoenvironment as non-marine, with wave-agitated waters. Fúlfaro (1970) found the presence of only one species, Pinzonella illusa, in deposits at the former Angatuba municipal slaughterhouse. At other fossiliferous sites in the Angatuba region, Pinzonella illusa, Holdhausiella elongata, Casterella gratiosa, Cowperesia camposi, Terraia aequilateralis, Favalia arcuata, Angatubia cowperesioides and Ferrazia cardinalis occur in silicified levels and coquina beds (Fúlfaro, 1970).

Two phytal ostracod assemblages that are characterized by elongated, smooth and poorly calcified carapaces and associated with microbial mats have been described in surface outcrops located in the Fazenda Monte Alegre region and are associated with the development of algae in the environment (Maranhão and Petri, 1996).
Sousa (1985) interpreted the paleoenvironment of the basal portion of the Passa Dois Group in the state of São Paulo as that of an epicontinental sea, initially of relatively deep, calm waters of the oceanic variety (Serra Alta Formation), followed by shallow coastal water environments formed by regression (Teresina Formation).

In the Angatuba region, in the cutting made for the Ivens Vieira-Angatuba access road, the Teresina Formation is described as alternating layers of sandstones, siltites, limestones, and chert (Fúlfaro, 1970; Sousa, 1985; Maranhão, 1995) up to its upper interface with the Pirambóia Formation. The uppermost portion of this cutting, near the location under study, is the upper portion of the Teresina Formation. This portion has a composition varying from very fine to silty sandstones to siltites and limestones, with layers of chert toward the top, to the occurrence of a paleosol (sedimentary breccia) that demarcates contact with the Pirambóia Formation (Sousa, 1985). At this location, Sousa (1985) interpreted a prograding tidal plain paleoenvironment ranging from intertidal to supratidal zones.

\section{MATERIALS AND METHODS}

The fossiliferous site under study is found at the location known as the Fazenda Monte Alegre $\left(23^{\circ} 30^{\prime} 57^{\prime \prime} \mathrm{S} / 48^{\circ} 23^{\prime} 59^{\prime \prime} \mathrm{W}\right)$, at a distance of approximately $3 \mathrm{~km}$ from the municipality of Angatuba (Figure 2). The site can be accessed via the Ivens Vieira Road (SP 204/270), which links the SP-270 Highway to Angatuba. Road cuttings occur from 


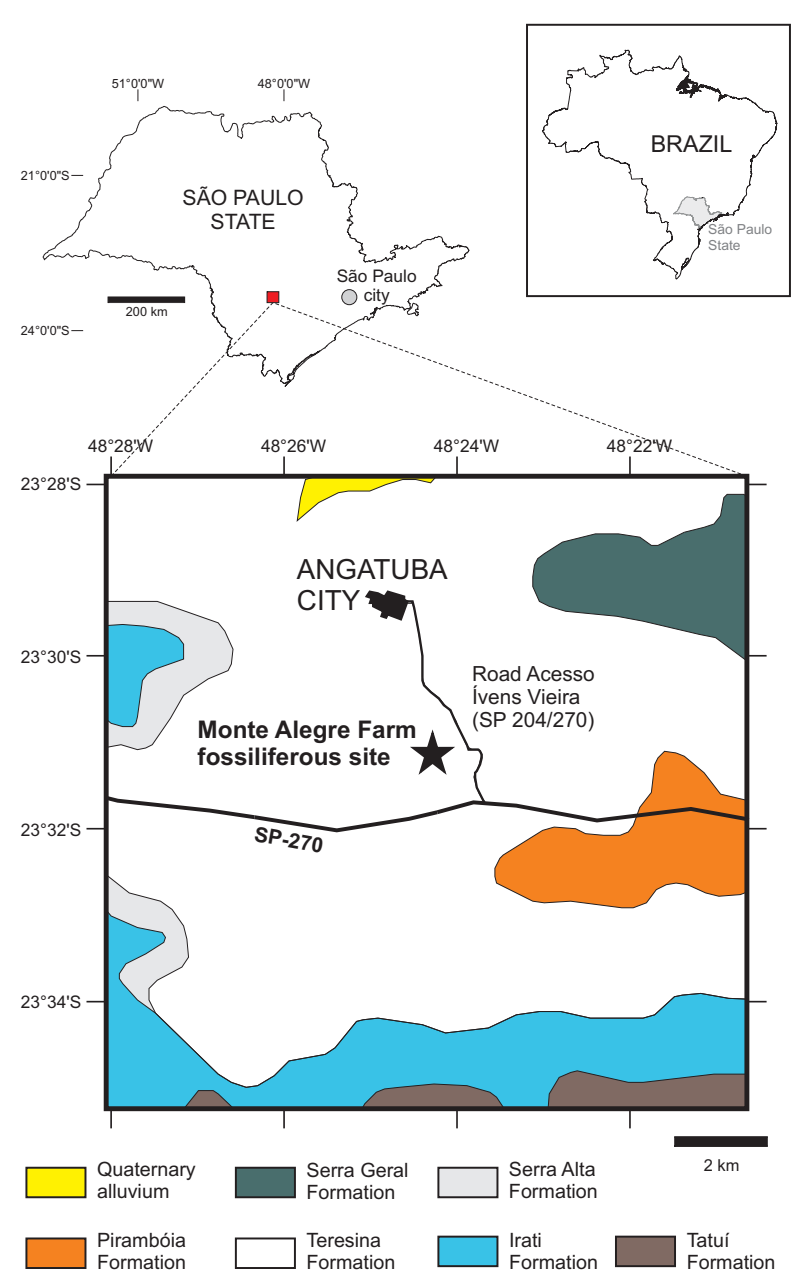

FIGURE 2. Geological and location map of the study area. Geological base: CPRM (2006).

the fossiliferous site to the SP-270 Highway. Along these cuttings are outcrops of the Teresina Formation rocks described by Fúlfaro (1970), Sousa (1985), and Maranhão and Petri (1996).

The fossils were described and photographed in the field. Representative samples of stromatolites were collected for study in the laboratory by cutting longitudinal and transverse polished sections. Thin sections were prepared to examine textural aspects, details of stromatolitic lamination, and micropaleontological content. The thin sections were prepared at the Rock Lamination Section of the Geosciences Institute (IGc-University of São Paulo). An optical microscope at the IGc-USP Microscopy Laboratory was used to describe the slides. The microfossils were analyzed using a SEM technique, including chemical analysis using energy dispersive spectrometry (EDS), at the IGcUSP Scanning Electron Microscopy Laboratory. The geochemical composition was determined using an X-ray fluorescence technique at the IGc-
USP X-Ray Fluorescence Laboratory, and mineralogical content was determined by X-ray diffraction at the Minerals and Rocks Identification Laboratory (LAMIR) of the Geology Department (Federal University of Paraná).

The most objective possible morphological criteria were adopted to differentiate the stromatolite morphotypes (Hofmann, 1969; Fairchild, 1993; Sallun Filho and Fairchild, 2004), avoiding the use of the taxonomic classification available for stromatolites because it lacks hierarchical biological criteria. The descriptions are according to the model adapted from Grey (1989), shown in Sallun Filho (1999).

The bivalve fossils associated with the stromatolites were collected for systematic and taphonomic study at the São Paulo State University (Unesp-Campus Bauru) Macroinvertebrate Paleontology Laboratory (LAPALMA). Until the mid1990s, there was no consensus in the literature regarding the systematic classification of bivalves of the Teresina Formation with respect to the number of genera and the systematic position of many taxa (Simões and Fittipaldi, 1987, 1988, 1992). The bivalves were classified in accordance with more recent systematic and cladistic proposals (Simões et al., 1997; Mello et al., 1998; Mello, 1999).

The samples described in this study are deposited in the paleontological collections of the Geological Institute (SMA/SP) and the UNESPBauru Macroinvertebrate Paleontology Laboratory (LAPALMA).

\section{RESULTS}

\section{Site Description}

The fossiliferous site constitutes a wide, smoothly sloped valley at the headwaters of the Córrego Catanduva creek, at an altitude of between 650 and $660 \mathrm{~m}$, at the base of the Serra de Angatuba highlands, where innumerous chert blocks are deposited with dimensions that are centimetric to metric (Figures 3.1-2). The site in question has been highly degraded due to the removal of blocks by the owner, so there is a risk that it will eventually cease to exist.

These blocks are not to be found in situ, having been transported, by gravity, from north to south with the headward erosion of the Serra de Angatuba (Angatuba Hill). It was found that the blocks originate from the same stratigraphic level as that of the Acesso Ivens Vieira-Angatuba road cutting, where a large biohermal structure was recognized (Sousa, 1985), or a structure of dubious 

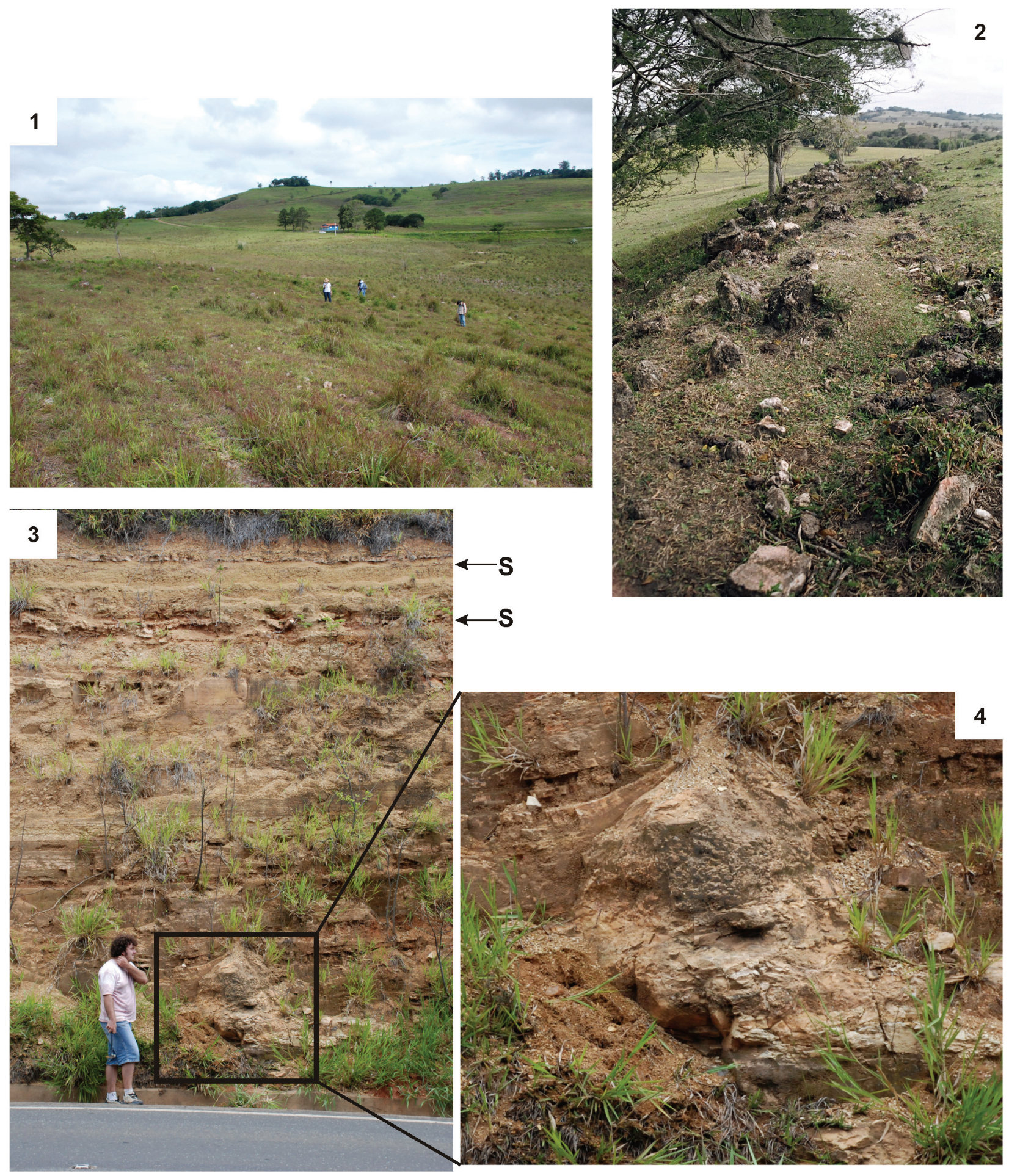

FIGURE 3.3.1 - General view of the location where silicified stromatolite blocks occur; 3.2 - Blocks of silicified stromatolites; 3.3 - Outcrops in the Acesso Ivens Vieira-Angatuba road cutting, with large silicified bioherms at the base (Figure 3.4) and silicified levels (S). 
nature (Fúlfaro, 1970). This cutting is situated at an elevation of 700 to $720 \mathrm{~m}$, near the top of the Serra de Angatuba (elevation of $790 \mathrm{~m}$ ) and topographically above the site under study.

The large silicified structures described by Fúlfaro (1970) and Sousa (1985) are still preserved in this cutting and are intercalated with sandstone and siltite layers (Figures 3.3 and 3.4). This structure is not solely biohermal, as a level occurs with the various silicified stromatolitic bioherms that is identical to the blocks of stromatolitic chert observed at the site under study. Due to the impossibility of visualizing the cutting three-dimensionally, it is not possible to observe such relationships between the bioherms as an alignment in plan view or their potential connections. Layers of chert are present toward the top of this cutting, some of which are found in the form of microbial mats. These layers have no connection to the bioherms, and they are not examined further in this study (Figures 3.3-4).

\section{Stromatolites}

The stromatolites show a light to dark reddish coloration, with black, dark brown, and beige portions (i.e., weathered portions). These stromatolites are essentially composed of microcrystalline quartz, with $98.4 \% \mathrm{SiO}_{2}$ and small quantities of aluminum, manganese, iron, barium, chromium, and phosphorous. The fenestral pores, secondary spaces and fractures are filled with chert and crystalline quartz.

The stromatolites occur in the form of isolated bioherms that are domed to subspherical with a flat base in profile and a rounded to lenticular shape in plan view (Figure 4). The internal macrostructure of these bioherms is generally composed of anastomosed, non-columnar, continuous lamination, with parallel to divergent growth (Figure 5). In some cases, the tops of the bioherms show structures in the form of "scales", which represent the lateral growth of individual column terminations in a divergent, anastomosed and individual manner (Figures 5.2-3). In other bioherms, the tops show concentric structures reflecting column terminations or a botryoidal texture that is formed by the junction of microcolumn terminations (Figures 6). The mesostructure of these bioherms exhibits a slightly convex to parabolic laminar profile, sometimes forming envelopes and even concentric lamination, and there is a low degree of laminar inheritance (Figures 5,7 ). Secondarily, divergent columnar forms occur, especially toward the top of the bioherms, with connections between the columns (Figure 7).
Despite the difficulty of visualizing stromatolitic lamination microscopically in the field, on petrographic slides, it is possible to observe fine lamination, which, in most cases, is well preserved, with alternating light and dark laminas (Figure 7.4). In some samples, lamination is absent due to alterations in the original lamination as a result of silicification.

In one sample, where microcolumns occur in a divergent arrangement forming a botryoidal texture at the top (Figures 8.1-2), microfossils of cyanobacteria and pluricellular chlorophytes that constitute part of the actual lamination were found to be present on a petrographic slide. Microfossils occur in the portion in which fine lamination is well preserved (Figure 8.3). Filamentous forms are arranged perpendicular to the lamination (Figures 8.5-6) and were identified as the genus Microcoleus, order Oscillatoriales (Figure 8.6), together with another two filamentous types, one being of the genus Rivularia, order Nostocales (Figures 8.79).

The degree of preservation of cyanobacteria included not only the mucilaginous sheath but also the entire cell wall (Figure 89). When analyzed using SEM, it was found that the filamentous cyanobacteria are three-dimensionally preserved, with their interior partially hollow or partially filled with the remains of organic matter (Figure 9). Chemical analysis using EDS (SEM) showed that the cell wall is composed of silica, which facilitated its good state of preservation, as it is stronger than the original carbonate (Figure 9).

\section{Coquina Beds}

Associated with the stromatolites, fossils of silicified bivalves are found to be preserved as coquinas, as already indicated by Sousa (1985). It was observed that the coquinas occur at the tops of the bioherms (Figure 10). Rare isolated specimens occur within the stromatolites and between the columns. The specimens described belong to the Pinzonella illusa biozone, with specific representatives of Pinzonella illusa, Angatubia cowperesioides and Houldausiella elongata (Figure 10).

Taphonomically, the fossiliferous concentration is preferentially preserved in coquinoid form. At least two distinct depositional events occurred during the formation of this coquina. The basal portion is characterized by the presence of bioclasts of difficult taxonomic classification that are disarticulated and chaotically dispersed throughout the matrix. Among these disarticulated shells, notable situations exist in which the valves are heaped, 

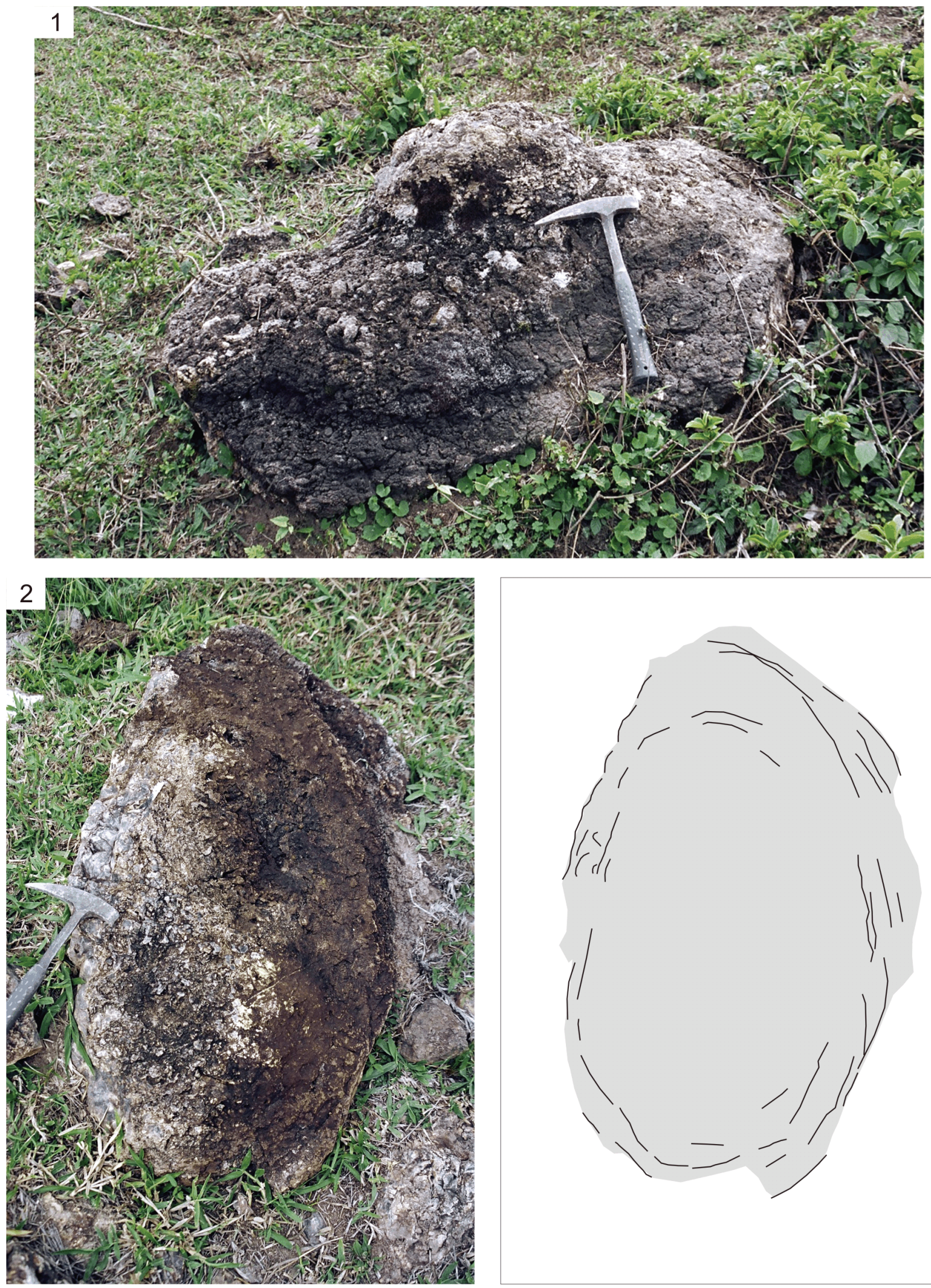

FIGURE 4.4.1 - Domed bioherm; 4.2 and 4.3 - Plan view of the lenticular bioherm. 

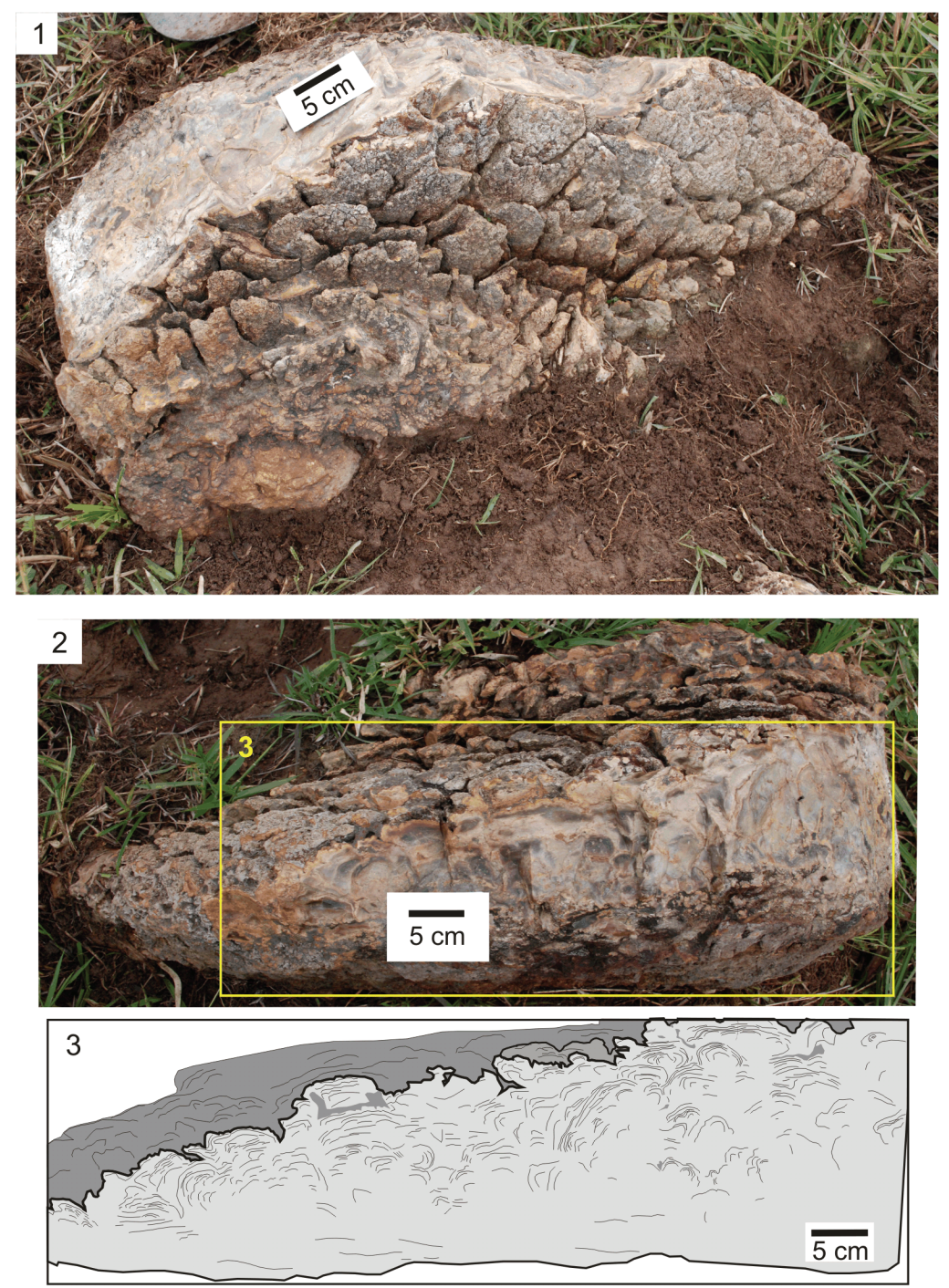

4

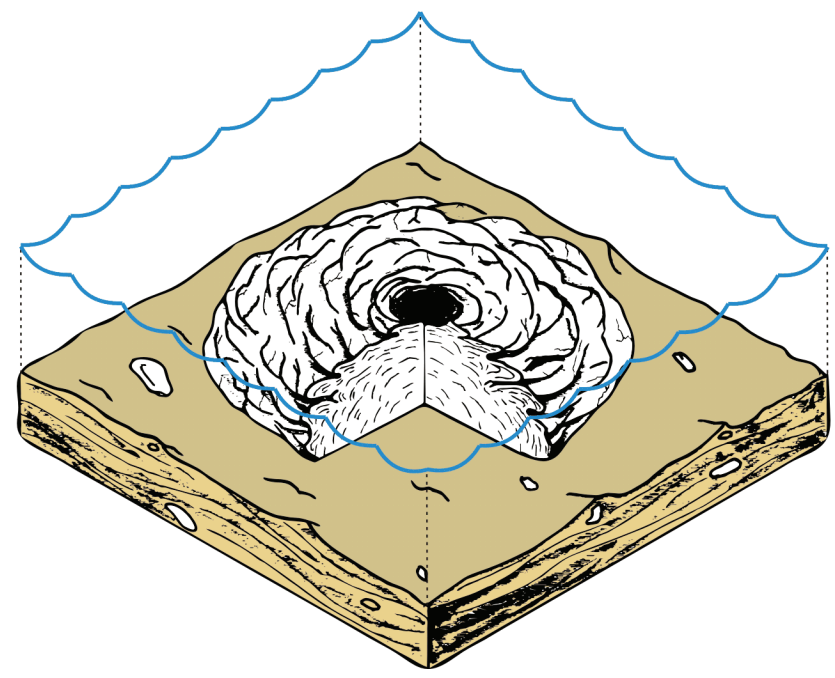

FIGURE 5. Bioherm with structure in the form of "scales" at the top (5.1) and macrostructure of anastomosed, nonisolated multiple columns showing parallel to divergent growth and a laminar profile ranging from slightly convex to parabolic in the longitudinal section (5.2-3); 5.4 - Three-dimensional model of the bioherm (Drawing by Raphael Galassi de Amorim). 

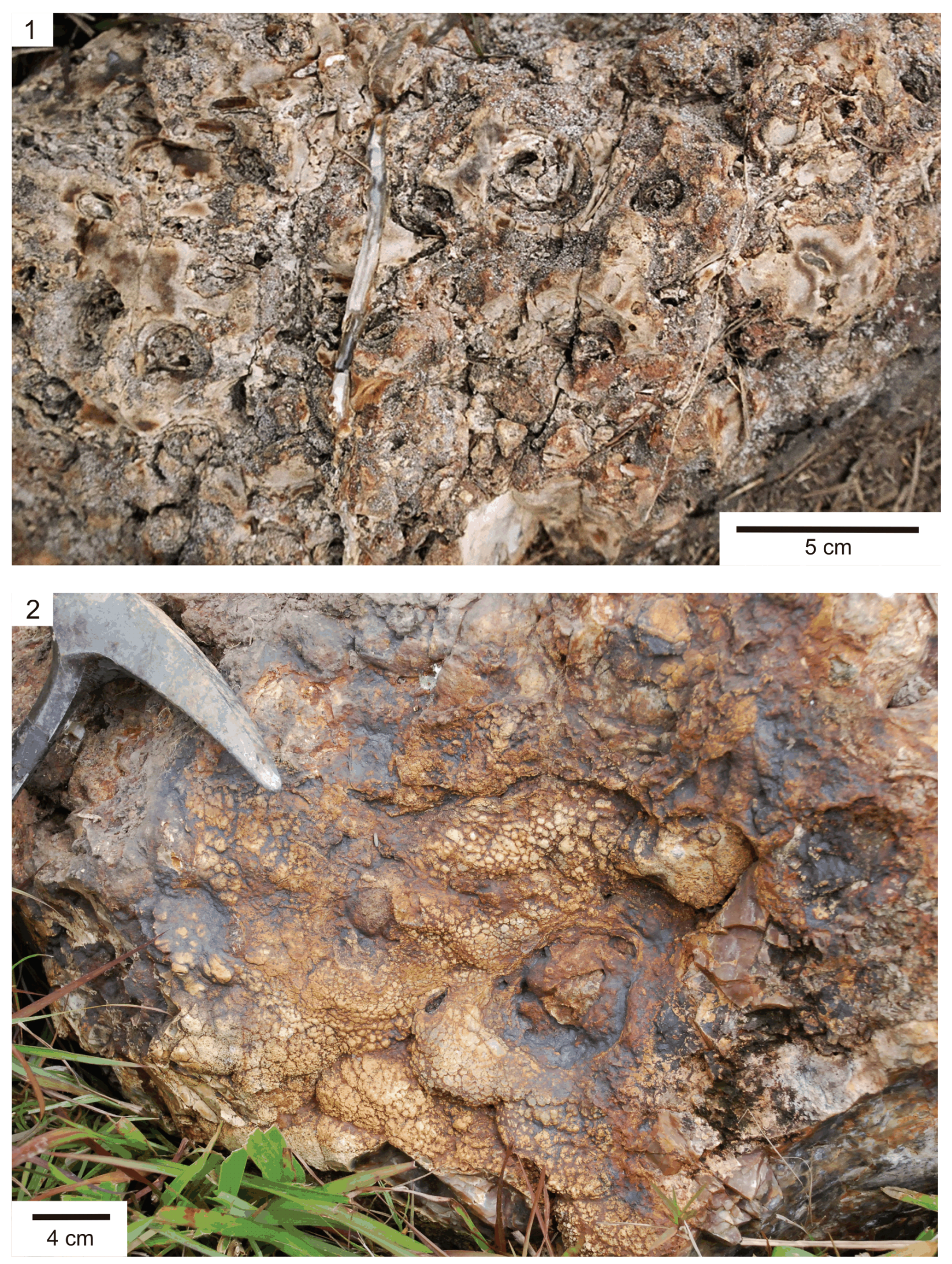

FIGURE 6. 6.1 - Concentric structures at the top of the bioherm; 6.2 - Botryoidal texture at the top of the bioherm. 

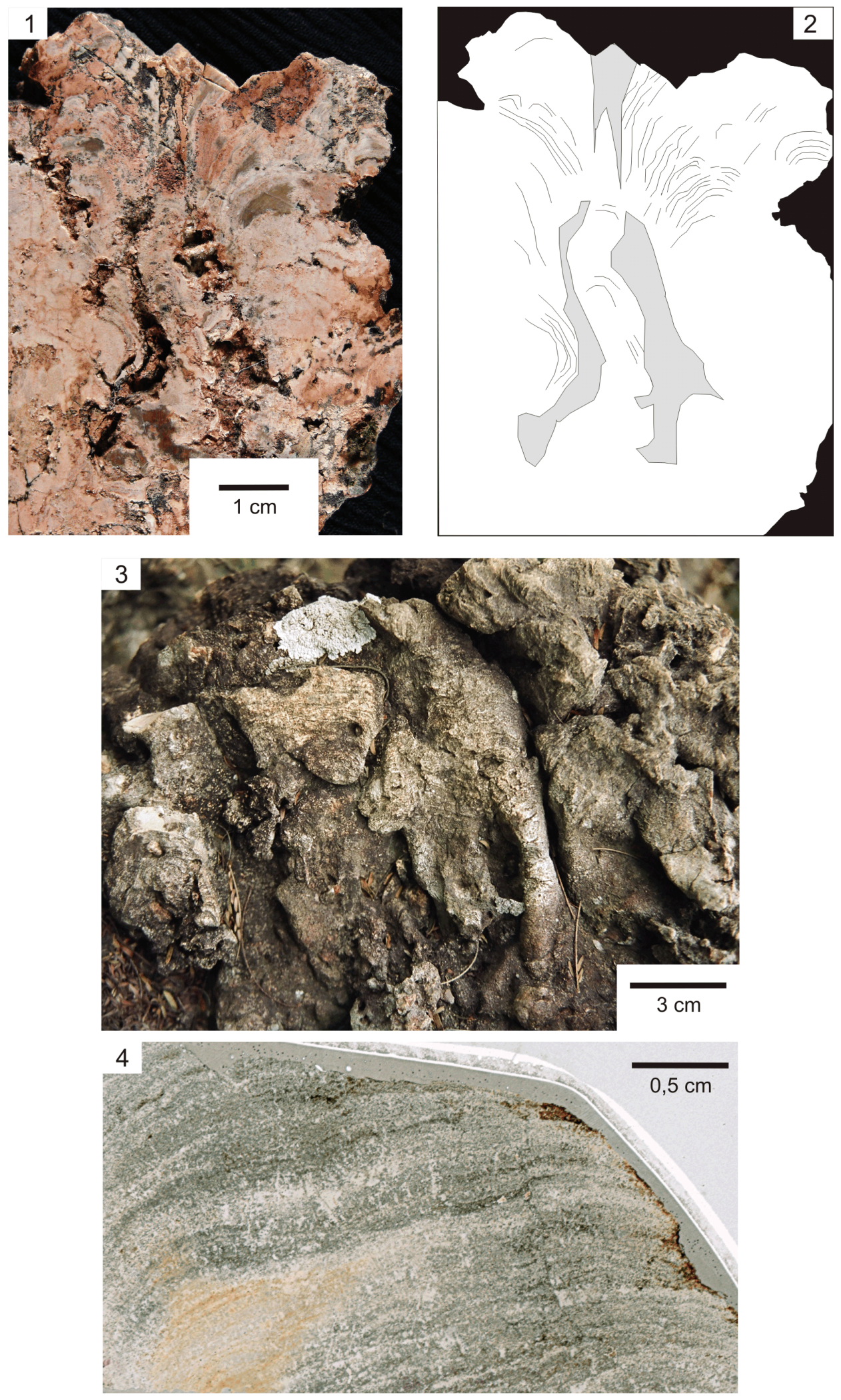

FIGURE 7. 7.1 and 7.2 - Individual columns with convex to parabolic lamination; 7.3 and 7.4 - Weathered bioherm exhibiting multiple columns and fine stromatolitic lamination with alternating light and dark laminas on a petrographic slide (7.4). 


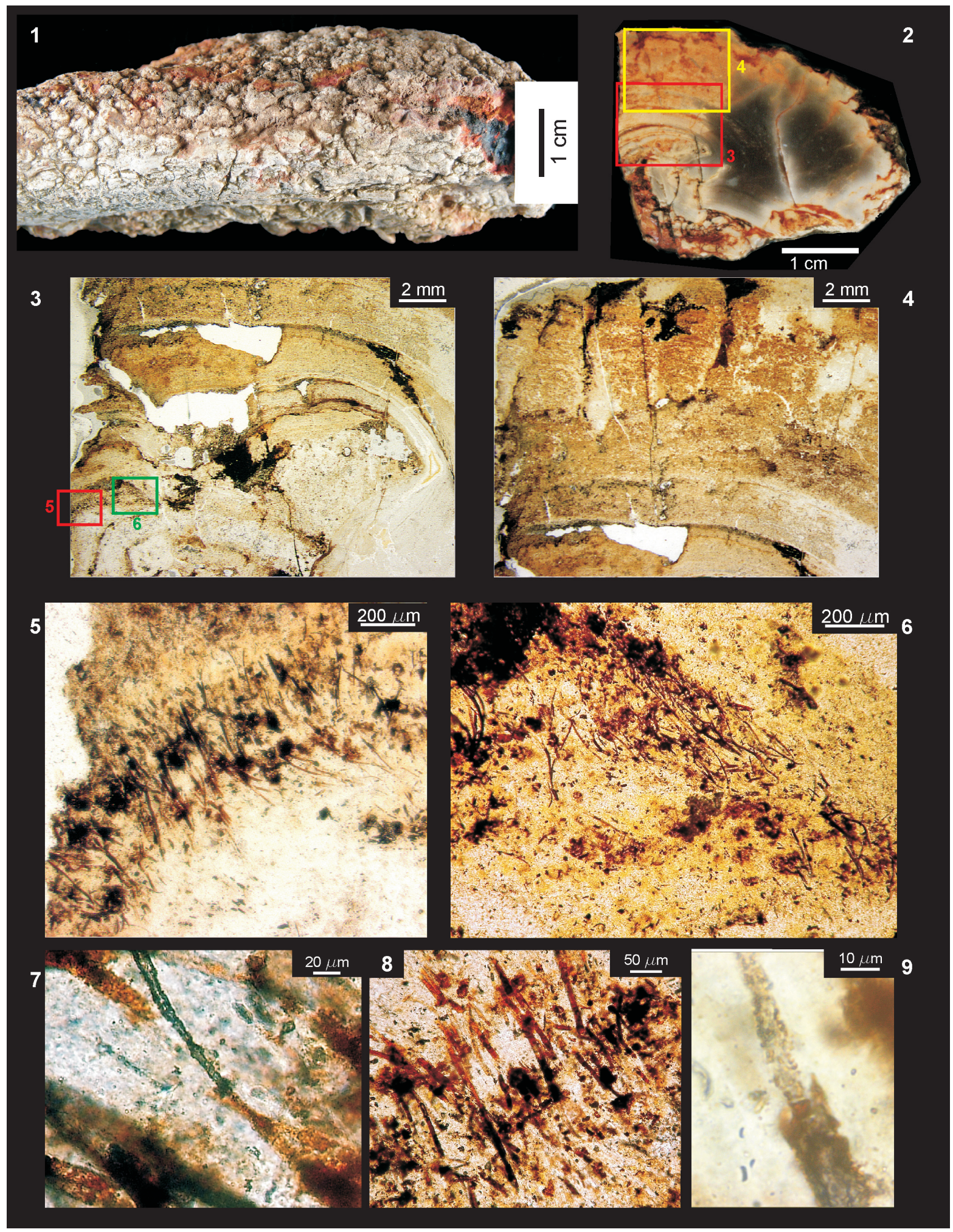

FIGURE 8. 8.1 - Microcolumns forming a botryoidal texture at the top of a bioherm; 8.2 - Longitudinal section showing lamination and a divergent arrangement of microcolumns; 8.3 - Fine stromatolitic lamination on a petrographic slide; 8.4 - Longitudinal petrographic slide showing the lamination and arrangement of microcolumns; 8.5 and 8.6 - Filamentous cyanobacteria arranged perpendicular to the lamination; 8.7 - Microcoleus; 8.8 - Rivularia; 8.9 - Detail of Rivularia showing a preserved mucilaginous sheath and cell wall. 


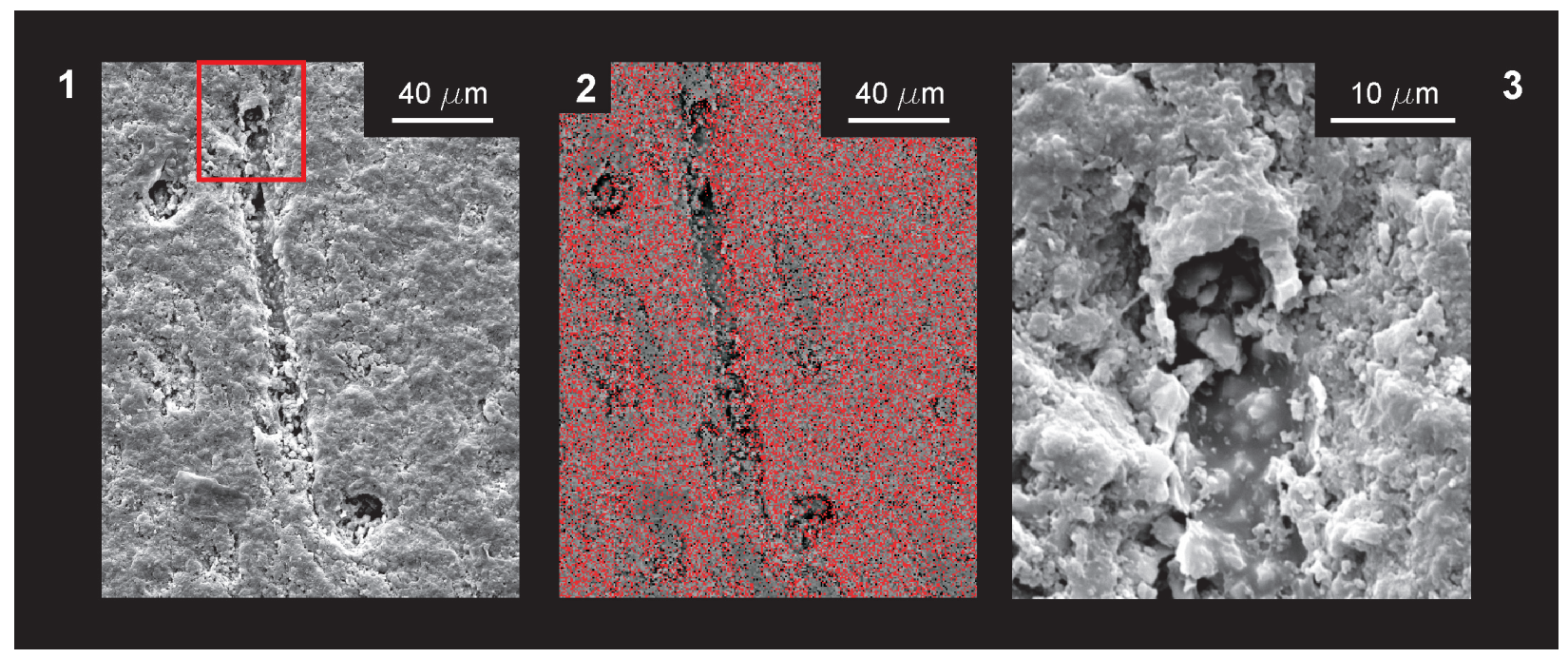

FIGURE 9. SEM images. 9.1 - Fossil of filamentous bacterium (secondary electrons); 9.2 - Fossil of 9.1 mapped by silica content via EDS (red) showing the high contents of the matrix and cell wall (backscattered electrons); 9.3 -Detail of a silicified cell wall and partially hollow interior (secondary electrons).

necessarily indicating the presence of turbulent flows during the genesis of these concentrations. Overlying this level are isolated valves and even joined valves.

The contact of the coquina with the upper portion of the stromatolite corresponds to the tops of the bioherms (Figure 10.3). Stromatolitic overgrowth in some bioclasts (Figure 10.5) belonging to the coquinoid portion is noted, indicating a probable period of shell exposure in the environment, i.e., in the Taphonomically Active Zone (TAZ) without significant energy flow.

\section{DISCUSSIONS}

The shapes of the stromatolites and the associated coquinas allowed the paleoenvironmental interpretation of part of the upper portion of the Teresina Formation. It is suggested that the environment would likely have been that of relatively calm and shallow waters. The ellipsoidal shape of some bioherms in plan view suggests the presence of weak marine currents. The low-relief domed shape and the divergent lateral growth greater than the vertical growth indicate waters with a depth of approximately 1 to $2 \mathrm{~m}$. Strong winds and low rainfall were also essential conditions for the formation of these structures, as was a water temperature of approximately $24^{\circ}$ degrees, drawing a comparison with the current formation environments of such structures.

The formation environment suggested for these stromatolites is likely associated with tidal plain environments with brackish shallow water of good luminosity. The restricted occurrence of stromatolites in certain stratigraphic levels could represent temporary periods of higher salinity. At that time, predation was reduced, given the extensive growth of large biohermal structures. Because of the thickness of the bioherms, such an environment was likely to have been stable for thousands of years.

Various authors question the salinity of the Teresina Formation waters. A saline to hypersaline environment is confirmed by the widespread presence of stromatolites, at least in levels specific to the upper portion of the Teresina Formation.

The presence of bivalves associated with stromatolites indicates an environment that was at least brackish (Ghilardi and Simões, 2002). Coquinas associated with the stromatolites likely indicate proximal tempestite, i.e., formation near the coastline (Torello and Simões, 1994). The death of the bivalves could be related to hypersalinity events. Silicified ooliths described in the Angatuba region and associated with disarticulated bivalves (Mendes, 1962; Fúlfaro, 1970) indicate that the environment was subject to the action of stronger currents or storms. Energy flow events likely directed the bioclasts until their deposition on the bioherms. The deposition of coquinas on the bioherms interrupted stromatolitic growth, causing their disappearance. From the point of view of energy flow, these events were followed by a long period of calm for the formation of stromatolites over the shells. 


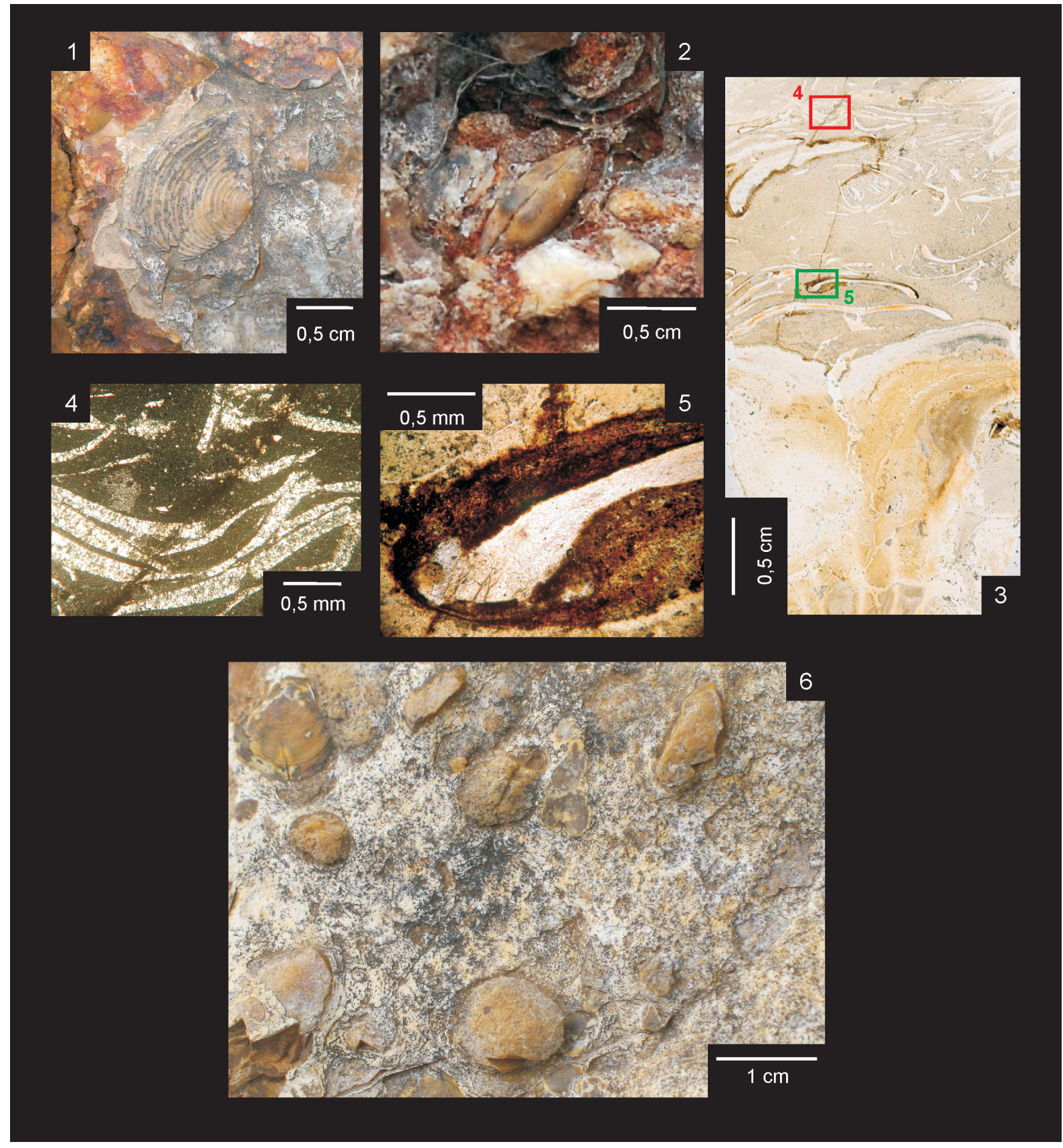

FIGURE 10. 0.1 - Angatubia cowperesioides; 10.2 - Articulated shell of Pinzonella illusa isolated at the top of a bioherm; 10.3 - Detail of coquina and top of the bioherm on a petrographic slide; 10.4 - Detail of coquina on a slide (10.3) with crossed nicols; 10.5 - Detail of stromatolitic overgrowth in bioclasts on a slide of coquina (10.3); F - Upper view of the fossiliferous concentration.

The texture of the bioherms, the presence of porosity (fenestral pores), and the bivalves and silicified microfossils indicate that the original carbonates have been replaced by silica. In addition, some microfossils have a hollow interior and a silicified cell wall, indicating early silicification. During burial, the inner contents of the cyanobacterial cells were degraded shortly before silicification (leaving an empty space). The time interval between burial and the silicification that allowed for good preservation of microbial remains was unlikely to have been greater than 8,000 years (Knoll, 1985). Silicification occurred during early diagenesis, given the excellent preservation of 
bivalves, microfossils, and stromatolitic microstructure. The petrification of Lycopodiopsis stems are interpreted as being favored by the alkalinity of a shallow marine environment in the Corumbataí and Teresina Formations (Faria and Ricardi-Branco, 2009).

\section{CONCLUSIONS}

The environment of the upper portion of the Teresina Formation would likely have been that of relatively calm and shallow waters with weak marine currents in a tidal plain environment with brackish shallow water of good luminosity. The occurrence of stromatolites in certain stratigraphic levels in the upper portion of the Teresina Formation could represent temporary periods of higher salinity.

The presence of bivalves associated with stromatolites indicates an environment that is at least brackish. Coquinas associated with the stromatolites likely indicate proximal tempestite, or the death of the bivalves could be related to hypersalinity events. Stronger currents, storms and high energy flow events directed the bioclasts until their deposition upon the bioherms, interrupting stromatolitic growth and causing their disappearance. These events were followed by a long period of calm for the formation of stromatolites over the shells.

The stromatolites were originally composed of carbonates replaced by silica in the early silicification process.

The environment interpreted for the upper portion of the Teresina Formation in this study is consistent with the described regression models and the introduction of continental depositional systems with the progressive closure of marine connections, which culminated in the establishment of an arid continental environment in the Mesozoic in the Paraná Basin.

\section{ACKNOWLEDGMENTS}

The authors thank R. Rohn Davies and M. (Instituto de Geociências e Ciências Exatas, UNESP) da Saudade Araújo Santos Maranhão Rosa (Instituto Geológico, SMA/SP) for their support during the fieldwork.

\section{REFERENCES}

Branco, F.R., Bernardes-de-Oliveira, M.E.C., and Garcia, M.J. 1999. Novos Elementos Tatoflorísticos da Formação Assistência, Subgrupo Irati, Grupo Passa Dois, Bacia do Paraná, provenientes de AngatubaSP, Brasil. Revista Universidade Guarulhos - Geociências, Guarulhos-SP, 6:85-95.

Castle, J.W. and Rodgers, J.H. Jr. 2009. Hypothesis for the role of toxin-producing algae in Phanerozoic mass extinctions based on evidence from the geologic record and modern environments. Environmental Geosciences, 16:1-23.

CPRM - Cia. de Pesquisa de Recursos Minerais 2006. Geologia e Recursos Minerais do Estado de São Paulo: Sistemas de Informações Geográficas (SIG). Brasília: MME, Programa Geologia do Brasil: Integração, Atualização e Difusão de Dados da Geologia do Brasil, Mapas Geológicos Estaduais escala 1:750000, CD-ROM.

de Almeida, F.F.M. 1944. Collenia itapevensis sp. n. - um fóssil pré-cambriano do Estado de São Paulo. Boletim Faculdade Filosofia Ciências e Letras, Univ. de São Paulo. XLV, Geologia 1:89-106.

de Almeida, F.F.M. 1954. Geologia do Centro-leste mato-grossense. Departamento Nacional da Produção Mineral, Div. de Geol. e Mineral (Bol. n 150).

Fairchild, T.R. 1993. Um método prático de descrição de estromatólitos para o geólogo de campo, p. 207. In Brazilian Paleontology Congress, 13, 1993. Abstracts. Brazilian Paleontological Society, São Leopoldo, Brazil.

Fairchild, T.R., Coimbra, A.M., and Boggiani, P.C. 1985. Ocorrência de estromatólitos silicificados na Formação Irati (Permiano) na borda setentrional da Bacia do Paraná (MT, GO). Anais Academia Brasileira de Ciências, 57:117.

Fanton, J.C.M., Ricardi-Branco, F., Ricardi, M.T., and Rohn, R. 2006. Reinvestigação da conífera permiana Krauselcladus (Formação Teresina, Bacia do Paraná, Brasil): novas interpretações morfológicas e anatômicas. Revista Brasileira de Paleontologia, 9:221-234.

Faria, R.S. and Ricardi-Branco, F. 2009. Guadalupian lycopsids from the Paraná Basin: Emendation of Lycopodiopsis derbyi Renault and a new species of Lepidophylloides, p. 84. In Brazilian Paleontology Congress, 21, 2009. Abstracts. Brazilian Paleontological Society, Belém, Brazil.

Ferreira-Oliveira, L.G. and Rohn, R. 2010. Leaiid conchostracans from the uppermost Permian strata of the Paraná Basin, Brazil: Chronostratigraphic and paleobiogeographic implications. Journal of South American Earth Sciences, 29:371-380.

Fúlfaro, V.J. 1970. Contribuição à geologia de Angatuba; Estado de São Paulo. Departamento Nacional da Produção Mineral, Div. de Geol. e Mineral, 83 p. (Bol. $\left.n^{\circ} 253\right)$. 
Ghilardi, R.P. and Simões, M.G. 2002. Foram os Bivalves do Grupo Passa Dois (Exclusive Formação Rio do Rasto), Neopermiano, Invertebrados Tipicamente Dulcícolas? Pesquisas em Geociências, 29:3-13.

Grey, K. 1989. Handbook for the study of stromatolites and associated structures, p. 82-171. In Kennard, J.M. and Burne, R.V. (eds.), Stromatolite Newsletter, v. 14, Bureau of Mineral Resources, Geology and Geophysics, Canberra, Australia.

Hofmann, H.J. 1969. Attributes of stromatolites. Geological Survey Canadian Paper 69-39.

Holz, M., França, A.B., Souza, P.A, lanuzzi, R., and Rohn, R. 2010. A stratigraphic chart of the Late Carboniferous/Permian succession of the eastern border of the Paraná Basin, Brazil, South America. Journal of South American Earth Sciences, 29:381-399.

Knoll, A.H. 1985. A paleobiological perspective on sabkhas, p. 406-425. In Friedman, G.M. and Krumbein, W.E. (eds.), Hypersaline Ecosystems - the Gavish Sabkha, vol. 53. Springer-Verlag, Berlin.

IPT - Instituto de Pesquisas Tecnológicas do estado de São Paulo 1981. Mapa geológico do Estado de São Paulo; escala 1:500000. Governo do estado de São Paulo. Secretaria da Indústria, Comércio, Ciência e Tecnologia.

Maranhão, M.S.A.S. 1995. Fósseis das formações Corumbataí e Estrada Nova do Estado de São Paulo: subsídios ao conhecimento paleontológico e bioestratigráfico. Unpublished Ph.D. Thesis, Instituto de Geociências, Universidade de São Paulo, São Paulo, SP, Brazil.

Maranhão, M.S.A.S. and Petri, S. 1996. Novas ocorrências de fósseis nas formações Corumbataí e Estrada Nova do estado de São Paulo e considerações preliminares sobre seus significados. Revista do Instituto Geológico, 17:33-54.

Mello, L.H.C. 1999. Análise Cládistica dos Bivalves do Grupo Passa Dois (Neopermiano), Bacia do Paraná, Brasil: implicações taxonômicas, evolutivas e paleobiogeográficas. Unpublished M.Sc. Dissertation, Instituto de Geociências, Universidade de São Paulo São Paulo, SP, Brazil.

Mello, L.H.C., Marques, A.C., Ghilardi, R.P., and Simões, M.G. 1998. Taxonomic position of the permian genera Anhembia and Leinzia and the phylogenetic consistency of the extinct family Megadesmidae (Bivalvia, Anomalodesmata), p. 53-54. In Hennig XVII, 1998. Program and Abstracts. Meeting of the Willi Hennig Society, São Paulo, Brazil. Willi Hennig Society, São Paulo.

Mendes, J.C. 1962. Lamelibrânquios permianos do oólito de Angatuba, Estado de São Paulo (Formação Corumbataí). Boletim da Sociedade Brasileira de Geologia, 11:37-56.
Milani, E.J. 1997. Evolução tectono-estratigráfica da bacia do Paraná e seu relacionamento com a geodinâmica fanerozóica do Gondwana sul-oriental. Unpublished Ph.D. Thesis, Instituto de Geociências, Universidade Federal do Rio Grande do Sul, Porto Alegre, RS, Brazil.

Milani, E.J., Melo, J.H.G., Souza, P.A., Fernandes, L.A., and França, A.B. 2007. Bacia do Paraná, p. 265-287. In Cartas Estratigráficas. Boletim de Geociencias da Petrobras, Rio de Janeiro, v. 15, n. 2.

Neregato, R., Souza, P.A., and Rohn, R. 2008. Registros palinológicos inéditos nas Formações Teresina e Rio do Rasto (Permiano, Grupo Passa Dois, Bacia do Paraná) - Implicações Biocronoestratigráficas e Paleoambientais. Revista Pesquisas em Geociências, 35(2):9-21.

Rocha-Campos, A.C., Basei, M.A., and Santos, P.R. 2009. Depósitos de cinza vulcânica no Neopaleozóico da Bacia do Paraná: datação radiométrica (SHRIMP) e possíveis implicações cronoestratigráficas e paleoambientais, p. 8. In Annual meeting of Brazilian Paleontological, 2009. Abstracts. Brazilian Paleontological Society - Nucleous SP, Guarulhos, Brazil.

Rohn, R. and Fairchild, T.R. 1986. Estromatólitos permianos em calcário coquinóide do Grupo Passa Dois, nordeste do Paraná. Anais da Academia Brasileira de Ciências, 58:433-444.

Sallun Filho, W. 1999. Análise dos estromatólitos do Grupo Itaiacoca (Proterozóico) ao sul de Itapeva, SP. Unpublished M.Sc.Dissertation, Instituto de Geociências, Universidade de São Paulo, São Paulo, SP, Brazil.

Sallun Filho, W. and Fairchild, T.R. 2004. Estromatólitos do Grupo Itaiacoca ao sul de Itapeva, estado de São Paulo, Brasil. Revista Brasileira de Paleontologia, 7:359-371.

Schubert, J.K. and Bottjer, D.J. 1992. Early Triassic stromatolites as post-mass extinction disaster forms. Geology, 20:883-886.

Simões, M.G. and Fittipaldi, F.C. 1987. Bivalves do Grupo Passa Dois, Permiano da Bacia do Paraná: sinopse das pesquisas, v. 1, p. 281-295. In VI Regional Geology Symposium, 1987. Atas. Brazilian Geological Society, Rio Claro, Brazil.

Simões, M.G. and Fittipaldi, F.C. 1988. A contribuição dos bivalves permianos da Bacia do Paraná ao estudo da evolução paleogeográfica, p. 50. In XV Brazilian Zoology Congress, 1988. Abstracts. Brazilian Zoological Society, Curitiba, Brazil.

Simões, M.G. and Fitipaldi, F.C. 1992. Fósseis da região de Rio Claro, SP. Arquivo do Município, Rio Claro.

Simões, M.G., Marques, A.C., Mello, L.H.C., and Anelli, L.E. 1997. Philogenetic analysis of the genera of the extinct family Megadesmidae (Pelecypoda, Anomalodesmata), with remarks on its paleoecology and taxonomy. Journal of Comparative Biology, 2:75-90. 
Sousa, S.H.M. 1985. Fácies Sedimentares das formações Estrada Nova e Corumbataí no Estado de São Paulo. Unpublished M.Sc. Dissertation, Instituto de Geociências, Universidade de São Paulo, São Paulo, SP, Brazil.

Souza, P.A. and Marques-Toigo, M. 2005. Progress on the palynostratigraphy of the Permian strata in Rio Grande do Sul State, Paraná Basin, Brazil. Anais da Academia Brasileira de Ciências, 77:353-365.
Suguio, K. and Sousa, S.H.M. 1985. Restos de mesossaurídeos na Formação Corumbataí, Permiano da Bacia do Paraná, no Estado de São Paulo. Anais da Academia Brasileira de Ciências, 57:339-347.

Torello, F.F. and Simões, M.G. 1994. Características tafonômicas da assembléia de Pinzonella illusa Reed, Formação Corumbataí (Neopermiano), Bacia do Paraná, Brasil. Acta Geologica Leopoldensia, 39:159-173.

Walker, J.D. and Geissman, J.W. (compilers) 2009. Geologic Time Scale. Geological Society of America, www.geosociety.org/science/timescale/timescl.pdf. 